\title{
Derek Szeto: RedFlagDeals.com A Case Study On When To Exit Your Successful Startup
}

Sean Wise, Ryerson University, Canada

Madelon Crothers, Ryerson University, Canada

\begin{abstract}
RedFlagDeals.com (RFD) is a daily virtual destination for over 450,000 Canadian consumers seeking and sharing coupons, promotions, and deals. Founder, Derek Szeto, created the website because he saw an unmet need in the Canadian market and did not hesitate to create something that is ten times better than spending hours each week clipping coupons on his kitchen counter. From the beginning, Derek and his team bootstrapped their way to the top. He built the business out of nothing in his parents' basement, with zero outside capital. He and his two employees funded the project themselves, without any external assistance. It was not until they had reached over a two million unique visitors that outside investors approached them to offer expansion funding (Naked Entrepreneur, 2013). Notwithstanding, Derek declined all offers of investment from outsiders.
\end{abstract}

February 2010 marked RFD's most rewarding milestone to date. Derek made the decision that he would sell to Yellow Pages Group Canada. After the transaction, Derek moved over to work under Yellow Pages Group Canada (YPGC) in the position of General Manager-Deals, Coupons, and Shopping. In late 2011, RFD was one of the 100 most popular websites in the country (Szeto, 2011). To this day, RFD attracts more than 2.5 million monthly readers by providing coupons and promotions across 14 categories (RedFlagDeals.com, 2013).

Keywords: Entrepreneurship; Bootstrapping; Domain Knowledge; Business Acumen; Pivoting; Value Proposition

\section{INTRODUCTION}

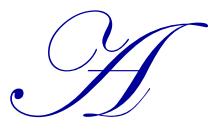

bird in the hand is worth two in the bush is a centuries old proverb that still has relevance to today's entrepreneurs. The proverb means it is preferable to have a small, but certain, return than a mere potential of a greater one. The proverb helps illustrate why outcome alone isn't sufficient to justify a decision, one must also recognize and account for probability of that outcome.

Founders invest their time, energy, capital, and lifeblood into creating their startup. When it comes time to sell (or "exit") the venture, each founder is faced with a decision - take today's small exit or raise more capital, grow the business, and hold out for a better priced exit; e.g. take today's "bird" or wait for tomorrow's "two birds." This was the issue Derek Szeto, faced when the Yellow Pages Group offered to buy his startup - RedFlagDeals.com.

RedFlagDeals.com (RFD) is a daily virtual destination for over 450,000 Canadian consumers seeking and sharing coupons, promotions, and deals. RFD offers - for online and offline companies - access to new customers (Naked Entrepreneur, 2013). Founder, Derek Szeto created the website because he saw an unmet need in the Canadian market and did not hesitate to create something that is ten times better than spending hours each week clipping coupons on his kitchen counter. By no means was Derek's creation of RFD an overnight success; he and his team experienced peaks and valleys, but it was his determination that allowed him to bootstrap his way into creating Canada's largest bargain-hunting community. 


\section{BACKGROUND}

Living in Oakville, Ontario, while in his last year of high school in 1999, Derek was like most other 18year-old Canadian youths. He had lots of friends, lots of parties, and lots of free time. Looking back on that time in his life, Derek describes himself as too lazy to go out and get a summer job at a restaurant, cutting grass, or working at the mall like his friends were. After all, Derek had successfully earned an acceptance to Queen's University in Kingston, Ontario, and he was looking forward to starting in the coming fall. So, in the summer of 1999, he found himself sitting on his parents' couch in their basement, looking at his diminishing balance in his bank account. He was determined that he needed to find a way to save himself money, especially when he was about to start university in a few months.

Even though Derek did not have a job, he enjoyed shopping. With limited income, he was always seeking to find the most optimal deal available on the products and services that suited his interests. At this time, there were many deals offered to American consumers online. Derek noticed that there were some amazing deals coming from large companies, such as Microsoft and other American software companies, but these deals were not available to him and his fellow Canadians. The Internet was just becoming popular and sitting in his parent's basement using their dial-up internet access, Derek began searching website after website, researching products, prices, and deal availability through many Canadian companies' websites. The more research Derek did, the more he saw a void in the market for Canadian consumers to find such deals.

Derek's passion for sharing great deals with the public continued throughout the creation of RFD, which is a free site for consumers. Users can easily access the site and browse the promotions in categories such as automotive, entertainment, kids and babies, travel, computer and electronics, small business, and more.

From the beginning, Derek and his team bootstrapped their way to the top. He built the business out of nothing in his parents' basement, with zero outside capital. He and his two employees funded the project themselves, without any external assistance. Derek's domain knowledge was weak in the beginning as his only real knowledge of online retail and couponing came from his own experiences. As a result, it was critical for Derek to build out his team by finding others who shared his same passion for seeking deals and promotions for the Canadian public. He purposely built his team based on their passion and level of domain, operational and business knowledge.

The value proposition that RFD offers the end consumer is saving money, making it an easy sell to Canadian consumers. Not only was this an unmet need in the Canadian marketplace at the time, but it also assisted RFD to go viral as saving money is usually at the top of consumers' list and Canadians take pride in how much they save. Word of mouth helped keep RFD user acquisition costs low as their website traffic continued to grow.

\section{FINDING THE UNIQUE VALUE PROPOSITION}

RFD was not an overnight success. In fact, like most eventual successes, there were many times when the RFD accountant was chasing down their account receivables out of fear that Derek wouldn't be able to make payroll that week. Late nights and early mornings became part of Derek's daily routine. Not only was he juggling launching RedFlagDeals.com; he was also doing so while earning his bachelor of commerce from Queen's University. Between class, projects, and school work, Derek would try and devote as much time as possible to RFD, but the heavy course load was only allowing for 2-4 hours a week of 'free' time to work on the business. He hired his close friend to join RFD at the beginning of his undergraduate degree to help out, especially during the peak season (Christmas and Boxing Day being the two busiest days of the year).

In November after his graduation from Queen's University, Derek moved to Toronto to open up RFD's first office in Toronto at the intersection of Yonge and Bloor streets. Initially, the office was very small, consisting of a couple of desks and chairs. The team (and office) of three grew as more employees were added month by month as the website began gaining traction. They outgrew their office in the downtown core and moved out to Liberty Village to accommodate the additional 10 employees that had joined the team. 
Derek's "aha moment" was when they fell into an opportunity to be featured on Toronto's local CityTV channel. Their morning television show had featured RedFlagDeals which was supposed to be a short mention of the company and what it offered consumers. Little did Derek and his team know that this would generate so much traffic that it crashed their servers, resulting in the RFD team saying to each other, "what have we created?" They were pleasantly surprised to learn that there were indeed enough consumers who cared about getting deals as much as they did.

\section{BUMPY ROAD OF GROWTH}

Once RFD established itself in the Canadian marketplace, they began looking to expand. Their initial thought was to introduce similar websites in other English language based communities (e.g. New Zealand). Since Derek and his team were still completely self funded and had limited resources, they decided not to pursue something at such a great distance. Looking back, had they engaged outside sources of capital, their expansion into other countries could have been a huge moment for RFD and its team.

In November 2005, Derek launched PriceCanada.com, a Canadian shopping comparison service that allowed consumers to compare prices, products, and retailers. Derek swiped (i.e., Steal With Integrity and Pride Everywhere) this concept from similar successful business models working in the United States. Unfortunately, there was not enough mass in the market or enough Canadian retailers selling electronics or similar products, forcing them to shut PriceCanada.com down as it was only breaking even. This was a pivoting moment for Derek and his team. They knew they had a potential opportunity at the fingertips but needed to focus on their strengthening RFD. Derek and his team turned all of their focus to RedFlagDeals.com.

Derek never really considered external funding. It was not until they had reached over two million unique visitors that outside investors approached them to offer expansion funding (Naked Entrepreneur, 2013). Notwithstanding, Derek declined all offers of investment from outsiders. He and his team were efficiently running and had grown from their initial lean team of two people to a small group of employees (e.g. 15-23).

\section{FUTURE UNCERTAIN}

Fast forward to January 2010. Derek had spent nearly a decade and an immeasurable number of hours on his passion project - Red Flag Deals. RFD now had offices at a new location on Queen Street in downtown Toronto and making payroll was no longer a concern for Derek. His life was good - he met the girl of his dreams, got married and started a family in all of what seemed to be a blink of an eye. The RFD team had grown to over 15 employees and companies were now coming to them wanting to advertise their deals on RFD. In 2004, Derek earned the title of CIBC's Student Entrepreneur of the Year for Ontario and an Ontario Finalist for the 2007 Ernst and Young Emerging Entrepreneur of the Year Award (Szeto, 2011).

To assist with strategy, a Board of Advisors emerged, consisting of industry leaders and experienced entrepreneurs to assist in the growth of RFD. Derek worked very closely with these advisors consulting on decisions regarding future growth and strategy. The Board believed that RFD had not yet reached its maximum potential; they believed that there was still more room to grow.

Between the growth of RFD and the growth of his family, Derek's days were still very busy. As a result, he was feeling pressure from all sides of his life to be present and available. From his perspective, he wanted to be spending more time at home with his wife and kids and the long hours at RFD's offices were beginning to limit the number of breakfasts and dinners he was having at home. That is when Derek received an offer to sell RFD to the Yellow Pages Group. The Yellow Pages Group was facing their own obsolesces, as Google had replaced people's need for their product. The Yellow Pages Group saw RFD as potential property to sell ads against.

Derek found himself wondering if he had taken RFD as far as he could. What was their next step? He pondered as his options and needs if he wanted to develop RFD into the next phase. In order to do so, he would have to raise millions in capital and give up part of his equity and control of his own company. Derek wondered if he had the time and energy in him to take on that challenge. After much consideration and thought, he saw only two options 
in front of him - take a deep breath and start the challenging process of raising the millions in capital that he needed or entertain some of the offers that were knocking at the door wanting to acquire RFD.

Raising capital to push RFD forward would allow Derek to continue being the decision maker within his company, but it would be a very challenging and lengthy process, resulting in him losing equity in RFD, and the long days and nights at the office would continue. If he decided to entertain one of the many external offers to purchase RFD, he would have a large financial gain, less day-to-day pressure on himself, thus allowing him to spend more mornings and nights at home with his family. Derek did not know what the right answer was, but he knew he could not take this type of decision lightly.

February 2010 marked RFD's most rewarding milestone to date. Derek made the decision that he would sell to Yellow Pages Group Canada. At the time, this seemed to be the best option. He felt a sale to Yellow Pages Group was a statement on the success Derek and his team had worked hard creating, and it would allow him to spend fewer nights at the office and more nights at home. However, it was a difficult decision to make; after all, RFD still had so much potential.

\section{CONCLUSION}

After the transaction, Derek moved over to work under the Yellow Pages Group Canada (YPGC) in the position of General Manager-Deals, Coupons, and Shopping. In this role, Derek oversaw business related deals leveraging RFD. It was, however, a hard transition for him to go from being his own boss to having to report to someone.

In September 2010, Derek helped RFD launch "Deal of the Day" which offers Canadian consumers substantial savings through a group buying service. Each day, similar to Groupon and LivingSocial.com, RedFlagDeals.com sends subscribers emails alerting them of the daily offer. Once a minimum number of consumers agreed to purchase the daily deal, the offer is activated and the buyers are able to use the deal. This type of group purchasing offers retailers a very low-risk model for collaborating with RFD as there are no set-up costs and merchants only have to pay for retail sales that are generated. This was a great way for RFD to work with small and medium sized businesses within Canada.

While in this new role, Derek was successful in doubling RFD's annual top line revenues post acquisition. Derek remained working for YPGC for just over two years before he decided to start working on his next projects.

Late in the year 2011, RFD was one of the 100 most popular websites in the country (Szeto, 2011). To this day, RFD attracts more than 2.5 million monthly readers by providing coupons and promotions across 14 categories (RedFlagDeals.com, 2013).

\section{DISCUSSION QUESTIONS}

1. Compare Derek's two options - raising external funding or exit and sell:

a. What were the key points to consider?

b. How would you decide which option to take?

2. If you were in Derek's position, would you have taken venture capital? Why? Why not?

3. If you were in Derek's position, would you have made the decision to sell, knowing that there was potential to grow with third party assistance?

4. Post sale, would you have stayed on with Yellow Pages Group to continue working on RFD?

\section{AUTHOR INFORMATION}

Dr. Sean Wise is a professor of entrepreneurship at the Ted Rogers School of Management at Ryerson University. He specializes in helping emerging and high growth potential organizations jump on the trajectory and turn a profit. $\mathrm{He}$ has over 15 years of seed funding experience and has helped found five business ventures of his own. Sean majored in engineering and economics at Carleton University; earning a law degree and MBA from the University 
of Ottawa and has recently completed his $\mathrm{PhD}$ in Business from the Adam Smith Business School at the University of Glasgow. E-mail: sean.wise@ ryerson.ca (Corresponding author)

Madelon Crothers is a graduate student in Digital Media at Ryerson University in Toronto, Ontario. She is a graduate of St. Lawrence College in Kingston, Ontario and completed her bachelor of commerce at Ryerson University in 2011. Before commencing her master's degree, she worked in Toronto in both digital marketing and social media within both small agencies and large corporations. She is expected to complete her masters in September 2014. E-mail: madelon.crothers@ ryerson.ca

\section{REFERENCES}

1. $\quad$ Bygrave, W., \& Zacharakis, A. (2011). Entrepreneurship (2nd ed.). Hoboken, NJ: Wiley.

2. $\quad$ Naked Entrepreneur. (2013, April 10). Derek Szeto. Retrieved October 14, 2013 from http://www.youtube.com/watch?v=8iOUdtJwD_c

3. RedFlagDeals.com. (n.d.). About Us. Retrieved 2013 03-10 from http://www.redflagdeals.com/info/about/

4. Szeto, D. (2011, November 11). Meditative blog: The digital results people. Retrieved 2013 1-October from http://blog.mediative.com/en/author/derek-szeto/

5. Szeto, D. (2013, October 29). Founder, RedFlagDeals.com. (M. Crothers, Interviewer) Toronto, Ontario, Canada.

6. Wise, S. (2009, April 6). The talent triangle. The Globe and Mail. Retrieved from http://www.theglobeandmail.com/report-on-business/the-talent-triangle/article1099632/?page=all 


\section{TEACHING NOTES}

\section{Bootstrapping}

Definition: to build a business out of nothing, with minimal outside capital (Bygrave \& Zacharakis, 2011)

From the beginning, Derek and his team bootstrapped their way to the top. They funded the project themselves, without any external assistance. Everything from website design to marketing to labour was done by Derek and his team, most of which was from his parents' basement or dorm room at Queen's University.

\section{Domain Knowledge}

Definition: having a thorough understanding of the industry and customers (Wise, 2010)

Attributes of successful management teams include three elements - business acumen, operational experience, and domain knowledge. All elements form the three corners of what is known as the talent triangle. The individual or individuals bringing domain knowledge to the team must understand the industry's key value motivators, posses the necessary relationships in the market to make sales and network as well as being aware of the domain's impediments, ensuring that the supply chain is not interrupted (Wise, 2010).

\section{Pivot/Pivoting}

Definition: to make required course corrections to dramatically improve the odds for success (Wise, 2010)

Determining there was not enough mass in the market or enough Canadian retailers selling electronics or similar products, forcing Derek and his team to shut down PriceCanada.com was a pivoting moment. He knew they had a potential opportunity at their fingertips, but needed to refine their business. Derek and his team pivoted their original idea that drove them to create RedFlagDeals.com.

\section{Value Proposition}

Definition: the value of a business' products and services to its customers (Bygrave \& Zacharakis, 2011)

RedFlagDeals.com is a virtual destination for over 450,000 consumers who are both seeking and sharing coupons, promotions, deals, and offers for both online and offline Canadian companies. The website offered consumers a solution that was ten times better than spending hours each week clipping coupons from multiple flyers and websites on their kitchen counters. 